\title{
TINJAUAN YURUDIS IMPLEMENTASI KETENTUAN PASAL 53 AYAT (3), AYAT (4), DAN AYAT (5) UNDANG UNDANG NOMOR 30 TAHUN 2014 TENTANG ADMINISTRASI PEMERINTAHAN
}

(Studi Putusan PTUN Surabaya Perkara Nomor 27/P.FP/2016/PTUN.SBY)

\author{
Agus Cunanto ${ }^{1}$, Nurbaedah ${ }^{2}$ \\ 1. Pemerintah Kabupaten Blitar \\ 2. Magister Hukum Program Pascasarjana Universitas Islam Kadiri
}

\begin{abstract}
ABSTRAK
Undang-Undang Nomor 30 Tahun 2014 Tentang Administrasi Pemerintahan merupakan hukum materiel di bidang Hukum Administrasi Negara berisi kaidah pokok penyelenggaraan pemerintahan dan sebagai dasar hukum penyelenggaraan pemerintahan. Salah satu permasalahan penting dalam penulisan tesis ini adalah mengenai implementasi ketentuan Pasal 53 ayat (3), ayat (4), dan ayat (5) Undang Undang Nomor 30 Tahun 2014 Tentang Administrasi Pemerintahan, yakni mengenai akibat hukum yang timbul sebagai akibat sikap diamnya Badan/Pejabat Pemerintahan atas permohonan yang diajukan warga kepadanya.Tujuan dari penelitian ini adalah untuk mengetahui arti azas fiktif negatif menurut Undang-Undang Nomor 5 tahun 1986 tentang Peradilan Tata Usaha Negara jo UU No. 9 Tahun 2004 jo UU No. 51 Tahun 2009 tentang Perubahan Kedua Atas UU No. 5 Tahun 1986 tentang Peradilan Tata Usaha Negara dan mengetahui arti azas fiktif positif menurut Undang-undang No.30 Tahun 2014 tentang Administrasi Pemerintahan, serta mengetahui bagaimana seharusnya implementasi ketentuan Pasal 53 ayat (3), ayat (4), dan ayat (5) tersebut didalam praktek peradilan.

Penelitian ini menggunakan metode yuridis normative, yaitu mengkaji kedudukan dan pelaksanaan ketentuan Pasal 53 ayat (3), ayat (4), dan ayat (5) Undang Undang Nomor 30 Tahun 2014 tentang Administrasi Pemerintahan.

Untuk mendapatkan bahan hukum diperoleh dengan cara membaca literature buku, majalah, makalah, internet, dan laporan hasil penelitian, berdasarkan metode yang digunakan, hasil penelitian yang diperoleh, bahwa ketentuan Pasal 53 ayat (3), ayat (4), dan ayat (5) Undang Undang Nomor 30 Tahun 2014 tentang Administrasi Pemerintahan bertujuan melindungi pemohon terhadap sikap diam Badandan/atau Pejabat pemerintahan, akan tetapi pada kenyataannya banyak masyarakat yang belum mengetahuinya.
\end{abstract}

\footnotetext{
ABSTRACT

In writing this thesis is devided into four chapters consisting of chapter 1 which containing the background of the problem, chapter II contains a literature review, chapter III contains the results of discussion and research, and chapter IV contains the cover.In writing this thesis, this has a problem about how the implementation of the provisions of Article 53 paragraph 3 paragraph 4 paragraph 5 of Law Number 30 in the year 2014 About Government Administration, about what law consequences arising from the silence of the Agency/Government in the application submitted by citizens to bim. While the aim of this research is to know the negative fictitious principle according to law number 5 in the year 1986 about State Administration Judicature jo of Law number 9 in the year 2004 jo of Law Number 51 in the year 2009 About the Second Amandment of Law Number 5 in the year 1986 About State Administration Judicature and to know the meaning of positive fictitious principles according to Law Number 30 in the year 2014 About Government Administration and to know howimplementation of the Provisions Article 53 paragraph (3), paragraph (4), and paragraph (5) of Law Number 30 in the Year 2014 About Government Adminitration on Administration of Governmen in judicial process.

This research uses the Normative Juridical method that examines the position and implementation of the Provisions Article 53 paragraph (3), paragraph (4), and paragraph (5) of Law Number 30 in the Year 2014 About Government Adminitration.The way to get legal materials is obtained by reading literature books, magazines,papers, internet, and research reports, Based $n$ the Methde used, research results that the Provisions Article 53 paragraph (3), paragraph (4), and paragraph (5) of Law Number 30 in the Year 2014 on Administration Government aims to protect the applicant against the abandonment of his petition, but in fact, many
} 
peple don't know about it, Therefore, besides improving judicial mechanisms, it is alsos needed to be socialized to the community, so that the implementation of the judiciary on the petition of the petitioner can be accounted for and should be increased in the contex of the a more dignified judicial process toward a better justice.

Keyword: Positive fictitious,government administration

\section{A. PENDAHULUAN}

Tuntutan terhadap peningkatan pelayanan publik yang semakin baik dan berkualitas terus menjadi harapan masyarakat, disamping untuk pemenuhan hak dan kebutuhannya, juga dalam rangka melaksanakan amanat Konstitusi.Terbitnya Undang-Undang Republik Indonesia Nomor 25 tahun 2009 tentang Pelayanan Publik merupakan wujud tuntutan masyarakat yang tidak dihindarkan, sehingga menjadi Pemerintah dituntut untuk terus memperbaiki kinerja pemerintahan dalam rangka memberikan pelayanan terbaik bagi masyarakat.

Pelayanan publik adalah kegiatan atau rangkaian kegiatan dalam rangka pemenuhan kebutuhan pelayanan sesuai dengan peraturan perundangundangan bagi setiap warga negara dan penduduk atas barang, jasa, dan/atau pelayanan administratif yang disediakan oleh penyelenggara pelayanan publik.

Dewasa ini penyelenggaraan pelayanan publik masih belum sesuai harapan masyarakat ,hal tersebut bisa disebabkan oleh ketidaksiapan untuk menanggapi terjadinya transformasi nilai yang berdimensi luas, terjadinya pergeseran kehidupan masyarakat serta menguatnya kesadaran masyarakat akan hak-haknya.

Tatanan baru masyarakat Indonesia dihadapkan pada harapan dan tantangan global yang dipicu oleh kemajuan di bidang ilmu pengetahuan, informasi, komunikasi, transportasi, investasi, dan perdagangan, menjadi kewajiban Negara untuk melayani setiap warga Negara dalam pemenuhan hak dan kebutuhan dasarnya,

Salah satu bentuk pelayanan publik yang sering mendapat keluhan dari masyarakat adalah dalam hal masyarakat membutuhkan bentuk surat keputusan sesuai dengan permohonan yang diinginkan oleh masyarakat seperti ijin, akta-akta, dan lain-lain, namun tidak terpenuhi karena sikap lalai Badan /Pejabat Tata Usaha Negara/Pejabat Pemerintah tanpa alasan yang dapat dipertanggungjawabkan, padahal masyarakat telah memenuhi persyaratan sesuai standar operasional prosedur (SOP).

Dengan terbitnya Undang-Undang Nomor 30 tahun 2014 tentang Administrasi
Pemerintahan penyelesaian terhadap permasalahan tersebut mendapat salurannya, yakni dengan menempuh melalui jalur litigasi atau jalur lembaga peradilan sehingga diharapkan menjadi media bagi masyarakat dalam memperoleh keadilan, yakni dengan mengajukan permohonan ke Pengadilan Tata Usaha Negara untuk mendapatkan putusan penerimaan permohonan atas keputusan dari Badan /Pejabat Tata Usaha Negara/Pejabat Pemerintah.

Hal dimaksud dimungkinkan oleh karena Undang - Undang Nomor 30 Tahun 2014 tentang Administrasi Pemerintahan menganut azas fiktif positif berbeda halnya dengan ketentuan sebelumnya sebagaimana diatur dalam Undang Undang No. 5 Tahun 1986 Tentang Peradilan Tata Usaha Negara, sebagaimana diubah dengan Undang Undang No. 51 Tahun 2009 tentang Perubahan Kedua Atas UU No. 5 Tahun 1986 tentang Peradilan Tata Usaha Negara yang menganut Azas Fiktif Negatif.

Untuk memahami perbedaan azas fiktif negative dan azas fiktif positif berikut dikemukakan beberapa istilah :

a. Pengertian Sengketa Tata Usaha Negara

Sengketa Tata Usaha Negara adalah sengketa yang timbul dalam bidang Tata Usaha Negara antara orang atau badan hukum perdata dengan Badan atau Pejabat Tata Usaha Negara, baik di pusat maupun di daerah, sebagai akibat dikeluarkannya Keputusan Tata Usaha Negara, termasuk sengketa kepegawaian berdasarkan peraturan perundang-undangan yang berlaku.

b. Pengertian Keputusan Tata Usaha Negara Keputusan Tata Usaha Negara adalah suatu penetapan tertulis yang dikeluarkan oleh Badan atau Pejabat Tata Usaha Negara yang berisi tindakan hukum Tata Usaha Negara yang berdasarkan peraturan perundangundangan yang berlaku, yang bersifat konkrit, individual dan final, yang menimbulkan akibat hukum bagi seseorang atau badan hukum perdata.

Termasuk Keputusan Tata Usaha Negara adalah Apabila badan atau pejabat tata 
usaha negara tidak mengeluarkan keputusan, sedangkan hal itu menjadi kewajibannya, maka hal tersebut disamakan dengan keputusan tata usaha negara.

c. Azas Fiktif Negatif

Dalam Peraturan Perundang undangan tidak terdapat definisi baku mengenai apa yang dimaksud Azas Fiktif Negatif.

Keputusan yang bersifat Fiktif Negatif adalah sikap diam Pejabat atau Badan Tata Usaha Negara yang tidak mengeluarkan keputusan Tata Usaha Negara yang dimohonkan oleh orang atau Badan Hukum Perdata, dalam kurun waktu tertentu, sedangkan hal tersebut menjadi kewajibannya, maka dengan berakhirnya kurun waktu kewajiban untuk mengeluarkan keputusan dimaksud dianggap sebagai penolakan.

d. Azas Fiktif Positif.

Keputusan yang bersifat Fiktif Negatif adalah sikap diam Pejabat atau Badan Tata Usaha Negara yang tidak mengeluarkan keputusan Tata Usaha Negara yang dimohonkan oleh orang atau Badan Hukum Perdata, dalam kurun waktu tertentu, sedangkan hal tersebut menjadi kewajibannya, maka dengan berakhirnya kurun waktu kewajiban untuk mengeluarkan keputusan dimaksud dianggap sebagai pengabulan/dikabulkan secara hukum.

e. Permohonan Guna mendapatkan Keputusan dan/Atau Tindakan Badan atau Pejabat Pemerintahan adalah permntaan yang diajukan secara tertulis kepada Pengadilan dalam hal permohnan dianggap dikabulkan secara hukum yang disebabkan Badan dan/atau Pejabat Pemerintahan tidak menetapkan Keputusan dan /atau melakukan tindakan.

f. Pemohonan adalah Pihak yang permohonannya dianggap dikabulkan secara hukum akibat tidak ditetapkannya Keputusan dan/atau Tindakan oleh Badan dan/atau Pejabat Pemerintahan dan karenanya mengajukan Permohonan kepada Pengadilan yang berwenang untuk mendapatkan putusan atas penerimaan Permohonan.

g. Termohon adalah Badan dan/atau Pejabat pemerintahan yang mempunyai kewajiban untuk menetapkan Keputusan dan/atau
Tindakan sebagaimana dimaksud dalam Permohonan dari Pemohon.

\section{B. METODE}

a. Lokasi Penelitian

Obyek Permasalahan dalam penelitian ini adalah putusan Pengadilan Tata Usaha Negara Surabaya dalam perkara Nomor: NO. 27/P.FP/2016/PTUN.SBY mengenai Permohonan untuk mendapatkan keputusan dan/atau tindakan Badan atau Pejabat Pemerintahan, yang diajukan oleh Sdr Yusuf Aminto warga Desa Jugo Kecamatan Kesamben Kabupaten Blitar yang meminta kepada PTUN agar Bupati Blitar selaku Termohon III menerbitkan Keputusan Bupati tentang Pengesahan dan Pengangkatan Kepala Desa jugo Kecamatan Kesamben Kabupaten Blitar atas nama Yusuf Aminto (Pemohon) yang dalam proses beracara diwakili Kuasa Hukumnya HOPALDES PIRMAN PANAILI, SH.MH.

b. Pengumpulan Data

Untuk membahas masalah ini, penulis menggunakan metode pendekatan Yuridis Normatif, karena bahan pustaka digunakan sebagai bahan utama yaitu : bahan hukum primer yang terdiri dari norma dasar atau kaidah, ketentuan atau peraturan dasar, serta peraturan perundang undangan. Selain itu digunakan pula bahan hukum skunder yaitubahan yang berasal dari Putusan Pengadilan Tata Usaha Negara Surabaya yang telah menyidangkan perkara berkaitan dengan persoalan yang dibahas dalamtesis ini.

\section{c. Pendekatan Masalah}

Metode pendekatan dalam penelitian hukum ini menitikberatkan pada studi kepustakaan yang berarti lebih banyak menelaah dan mengkaji aturan aturan hukum yang ada dan berlaku disampingmemerlukan bahan bahan hukum skunder karena akan berfungsi untuk melengkapi dan menunjang bahan hukum dalam penelitian kepustakaan.

d. Sumber Bahan Hukum

Untuk memahami permasalahan dalam penulisan ini, digunakan Metode Pengolahan Data Kualitatif

Bahan Hukum Primer.Yaitu bahan bahan berupa aturan yang isinya mempunyai kekuatan hukum mengikat pada masyarakat 
yaitu berupa peraturan perundang undangan

Bahan Hukum Skunderyaitu bahan hukum yang isinya menjelaskan mengenai bahan hukum Primer, bahan hukum skunder sebagai bahan hukum yang isinya tidak mempunyai kekuatan hukum mengikat tetapi berperan untuk menjelaskan mengenai bahan hukum primer yang merupakan hasil bahan pendapat atau pikiran para pakar atau ahli yang mempelajari suatu bidang tertentu secara khusus yang akan memberikan petunjuk kemana peneliti akan mengarah.

e. Analisis Data

MetodeAnalisis Data yang penulis gunakan dalam penulisan Tesis ini adalah :

1) Analisa PeraturanMetode ini penulis gunakan dalam mengumpulkan bahan hukum primer yang dilakukan dengan menganalisa ketentuan ketentuan yang dirumuskan dalam peraturan perundang undangan yang berlaku di Indonesia yang berkaitan dengan Adminsitrasi Pemerintahan, Hukum Peradilan Tata Usaha Negara dan Acara Peradilan Tata Usaha Negara khususnya berkaitan dengan permohonan Untuk Memperoleh Putusan atas Penerimaan Permohonan Guna Mendapatkan Keputusan dan/atau Tindakan Badan atau Pejabat Pemerintahan.

2) Studi Literatur.Metode ini penulis gunakan dalam mengumpulkan bahan hukum skunder yang dilakukan dengan membaca buku- buku, putusan PTUN dan/ atau bahan yang berkaitan dengan masalah yang dikaji, dengan menggunakan metode ini dapat diperoleh landasan teori dan dasar dasar hokum.

\section{HASIL PENELITIAN}

Dari hasil penelitian Penulis di Pengadilan Tata Usaha Negara Surabaya, maka Pengadilan Tata Usaha Negara Surabaya telah beberapa kali menggelar sidang permohonan untuk mendapatkan putusan atas penerimaan permohonan sebagaimana diatur dalam Peraturan Mahkamah Agung Nomor 5 Tahun 2015 yang kemudian disempurnakan dengan Peraturan mahkamah Agung Nomor 8 Tahun 2017 tentang Pedoman Beracara Untuk
Memperoleh Putusan atas Penerimaan Permohonan Guna Mendapatkan Keputusan dan/atau Tindakan Badan atau Pejabat Pemerintahan.

Salah satu perkara yang disidangkan oleh Pengadilan Tata Usaha Negara Surabaya adalah dilangsungkannya sidang perkara perkara Nomor: NO. 27/P.FP/2016/PTUN.SBY.

Yang menjadi Obyek Permasalahan dalam perkara Nomor: NO. 27/P.FP/2016/PTUN.SBY mengenai Permohonan untuk mendapatkan keputusan dan/atau tindakan Badan atau Pejabat Pemerintahan, yang diajukan oleh Sdr Yusuf Aminto warga Desa Jugo Kecamatan Kesamben Kabupaten Blitar yang meminta kepada PTUN agar Bupati Blitar selaku Termohon III menerbitkan Keputusan Bupati tentang Pengesahan dan Pengangkatan Kepala Desa jugo Kecamatan Kesamben Kabupaten Blitar atas nama Yusuf Aminto (Pemohon) yang dalam proses beracara diwakili Kuasa Hukumnya HOPALDES PIRMAN PANAILI, SH.MH.

\section{PEMBAHASAN}

a. Azas Fiktif Negatif.

Sesungguhnya Objek gugatan dalam Fiktif Negatif tidak berwujud, tetapi suatu sikap tidak mengeluarkan Keputusan yang telah dimohonkan kepadanya sedangkan hal itu menjadi kewajibannya, maka hal tersebut dianggap sebagai Penolakan, sikap Badan atau Pejabat Tata Usaha Negara tersebut dapat menjadi objek gugatan di Pengadilan Tata Usaha Negara atau menganut Azas Fiktif Negatif.

Ketentuan Azas Fiktif Negatif dapat ditemukan dalam ketentuan Pasal 3 ayat (2) dan Ayat (3) Undang Undang No. 5 Tahun 1986 Tentang Peradilan Tata Usaha Negara, sebagaimana diubah dengan Undang Undang No. 51 Tahun 2009 tentang Perubahan Kedua Atas Undang-Undang No. 5 Tahun 1986 tentang Peradilan Tata Usaha Negara yang berbunyi :

(2) Jika suatu badan atau pejabat tata usaha negara tidak mengeluarkan keputusan yang dimohon, sedangkan jangka waktu sebagaimana ditentukan dalam peraturan perundangundangan dimaksud telah lewat, maka badan atau pejabat tata usaha negara tersebut dianggap telah menolak 
$\begin{array}{lr}\text { (3) Dalam hal } & \text { peraturan } \\ \text { perundangundangan } & \text { yang }\end{array}$ bersangkutan tidak menentukan jangka waktu sebagaimana dimaksud dalam ayat (2), maka setelah lewat jangka waktu empat bulan sejak diterimanya permohonan, badan atau pejabat tata usaha Negara yang bersangkutan dianggap telah mengeluarkan keputusan penolakan.

Dengan demikian sikap diam Pejabat atau Badan Tata Usaha Negara yang tidak mengeluarkan keputusan Tata Usaha Negara yang dimohonkan oleh orang atau Badan Hukum Perdata, dalam kurun waktu tertentu, sedangkan hal tersebut menjadi kewajibannya, maka dengan berakhirnya kurun waktu kewajiban untuk mengeluarkan keputusan dimaksud, dianggap sebagai Keputusan Tata Usaha Negara yaitu Keputusan dianggap sebagai penolakan.

b. Azas Fiktif Positif Undang - Undang Nomor 30 Tahun 2014 tentang Administrasi Pemerintahan

Sebagaimana Azas Fiktif Negatif yang tidak diatur secara tegas, maka Azas Fiktif Positif juga tidak ada definisi baku yang diatur dalam peraturan perundang undangan, bahkan dalam Undang - Undang Nomor 30 Tahun 2014 tentang Administrasi Pemerintahanjuga tidak mengatur.

Berlakunya Undang - Undang Nomor 30 Tahun 2014 tentang Administrasi Pemerintahan melahirkan adanya paradigma baru terkait dengan sikap diam atau pengabaian oleh Badan dan/atau Pejabat Pemerintahan atas suatu permohonan masyarakat untuk dapat memperoleh keputusan dari Badan dan/atau Pejabat Pemerintahan.

Sebagaimana uraian tersebut diatas, meskipun ketentuan tentang adanya Keputusan yang Fiktif Positif tidak diatur secara tersurat dan eksplisit dalam Undang Undang Nomor No. 30 Tahun 2014 tentang Administrasi Pemerintahan, namun Azas tersebut dapat kita temukan dengan menggunakan pendekatan asas hukum, yaitu asas posterior derogate legi priori.
Asas posterior derogate legi prioriyang berarti peraturan perundang undangan yang baru mengesampingkan peraturan perundang undangan yang terdahulu.

Dengan menggunakan Azas Hukum tersebut maka Azas fiktif positif dapat ditemukan dari makna ketentuan Pasal 53 ayat (3) Undang -undang No.30 Tahun 2014 tentang Administrasi Pemerintahan berbunyi :

(3) Apabila dalam batas waktu sebagaimana dimaksud pada ayat (2), Badan dan/atau Pejabat Pemerintahan tidak menetapkan dan/atau melakukan Keputusan dan/atau Tindakan, maka permohonan tersebut dianggap dikabulkan secara hukum.

Berdasarkan ketentuan di atas, maka pemohon dalam hal ini adalah pihak yang permohonannya dianggap dikabulkan secara hukum akibat tidak ditetapkannya Keputusan dan/atau tidak dilakukannya tindakan oleh badan dan/atau pejabat pemerintahan dan karenanya dapat mengajukan permohonan kepada Pengadilan yang berwenang untuk mendapatkan putusan atas penerimaan permohonan.

a. Kedudukan Peraturan Mahkamah Agung Nomor 8 Tahun 2017 tentang Pedoman Beracara Untuk Memperoleh Putusan atas Penerimaan Permohonan Guna Mendapatkan Keputusan dan/atau Tindakan Badan atau Pejabat Pemerintahan ri Perspektif hierarkhis peraturan perundang undangan.

Mekanisme yang mengatur tata cara mengajukan permohonan kepada Pengadilan yang berwenang untuk mendapatkan putusan atas penerimaan permohonan diatur dalam Peraturan Mahkamah Agung Nomor 5 Tahun 2015 yang kemudian disempurnakan dengan Peraturan mahkamah Agung Nomor 8 Tahun 2017 tentang Pedoman Beracara Untuk Memperoleh Putusan atas Penerimaan Permohonan Guna Mendapatkan Keputusan dan/atau Tindakan Badan atau Pejabat Pemerintahan.

1. Kedududukan Peraturan mahkamah Agung Nomor 5 Tahun 2015 diperbaharui Peraturan mahkamah Agung Nomor8 Tahun 2017 terhadap 
Undang Undang Nomor 12 Tahun 2011 Tentang Pembentukan Peraturan Perundang Undangan.

Dalam sistem perundang undangan dikenal adanya hierarki peraturan perundang undangan, Peraturan perundang undangan tersusun secara bertingkat dari tingkat yang lebih tinggi sampai perundang undangan dengan tingkatan yang lebih rendah.

Kekuatan hukum masing - masing peraturan perundang undangan adalah sesuai tingkatan hierarki tersebut semakin tinggi tingkatan peraturan perundang undangan maka semakin tinggi pula kedudukannya dibanding dengan peraturan perundang undangan yang tingkatannya lebih rendah.

Pengaturan mengenai jenis dan hierarki peraturan perundang undangan di Indonesia saat ini diatur dalam Undang Undang Nomr 12 Tahun 2011 Tentang Pembentukan Peraturan Perundang Undangan.

Dalam Pasal 7 disebutkan bahwa :

(1) Jenis dan hierarki Peraturan Perundangundangan terdiri atas:
a. Undang-Undang
Republik Indonesia'Tahun 1945;
Dasar Negara
b. Ketetapan Majelis Permusyawaratan Rakyat;
c. Undang-Undang/Peraturan
Pemerintah Pengganti Undang- Undang;
d. Peraturan Pemerintah;
e. Peraturan Presiden;
f. Peraturan Daerah Provinsi; dan
g. Peraturan Daerah Kabupaten/Kota.

(2) Kekuatan hukum Peraturan Perundangundangan sesuai dengan hierarki sebagaimana dimaksud pada ayat (1).

Meskipun dalam ketentuan Pasal 7 ayat (1) Undang - Undang Nomor 12 Tahun 2011 Tentang Pembentukan Peraturan Perundang Undangan.tidak mencantumkan secara eksplisit Peraturan Mahkamah Agung sebagai salah satu jenis peraturan perundang undangan, namun hal tersebut bukan berarti Peraturan Mahkamah Agung tersebut tidak memiliki landasan hukum.

Hal ini bisa kita maknai dari bunyi ketentuan Pasal 8 ayat (1) dan ayat (2) Undang Undang Nomor 12 Tahun 2011 Tentang Pembentukan Peraturan Perundang Undanganyang berbunyi :

Pasal 8
(1) Jenis Peraturan Perundang-undangan selain sebagaimana dimaksud dalam Pasal 7 ayat (1) mencakup peraturan yang ditetapkan oleh Majelis Permusyawaratan Rakyat, Dewan Perwakilan Rakyat, Dewan Perwakilan Daerah, Mahkamah Agung, Mahkamah Konstitusi, Badan Pemeriksa Keuangan, Komisi Yudisial, Bank Indonesia, Menteri, badan, lembaga, atau komisi yang setingkat yang dibentuk dengan Undang-Undang atau Pemerintah atas perintah Undang-Undang, Dewan Perwakilan Rakyat Daerah Provinsi, Gubernur, Dewan Perwakilan Rakyat Daerah Kabupaten/Kota, Bupati/Walikota, Kepala Desa atau yang setingkat.

(2) Peraturan Perundang-undangan sebagaimana dimaksud pada ayat (1) diakui keberadaannya dan mempunyai kekuatan hukum mengikat sepanjang diperintahkan oleh Peraturan Perundang-undangan yang lebih tinggi atau dibentuk berdasarkan kewenangan.

\section{E. KESIMPULAN}

Berdasarkan uraian tersebut diatas maka dapat ditarik kesimpulan sebagai berikut:

1. Berlakunya Undang Undang Nomr 30 Tahun 2014 Tentang Administrasi Pemerintahan menyebabkan terjadinya pergeseran makna terhadap Sikap diam Badan dan/atau Pejabat Pemerintahan yang tidak mengeluarkan Keputusan yang dimohonkan oleh Pemohon/Masyarakat.

a. Undang Undang No. 5 Tahun 1986

Tentang Peradilan Tata Usaha Negara, sebagaimana diubah dengan Undang Undang No. 51 Tahun 2009 tentang Perubahan Kedua Atas UndangUndang No. 5 Tahun 1986 tentang Peradilan Tata Usaha Negara menganut Azas Fiktif Negatif, sebagaimana diatur dalam ketentuan Pasal 3 ayat (2) dan Ayat (3) . Sikap diam Pejabat atau Badan Tata Usaha Negara yang tidak mengeluarkan keputusan Tata Usaha Negara yang dimohonkan oleh orang atau Badan Hukum Perdata, dalam kurun waktu tertentu, sedangkan hal tersebut menjadi kewajibannya, maka dengan berakhirnya kurun waktu kewajiban untuk mengeluarkan keputusan dimaksud , dianggap sebagai Keputusan Tata Usaha 
Negara yaitu Keputusan dianggap sebagai penolakan.

b. Undang - Undang Nomor 30 Tahun 2014 Tentang Administrasi Pemerintahan yang diundangkan dalam Lembaran Negara Republik Indonesia Tahun 2014 Nomor 292, dan Tambahan Lembaran Negara Nomor 5601, yang mulai berlaku pada tanggal 17 Oktober 2014 menganut Azas Fiktif Positif sebagaimana diatur dalam ketentuan Pasal 53 Undang Undang Nomor 30 Tahun 2014 Tentang Administrasi Pemerintahan ,Sikap Badan dan/atau Pejabat Pemerintahan yang tidak memenuhi permohonan masyarakat untuk menetapkan Keputusan dan/tindakan yang menjadi kewajibannya, maka dianggap sebagai sikap mengabulkan atau dikabulkan secara Hukum.

c. Terbitnya Undang - Undang Nomor 30 Tahun 2014 Tentang Administrasi Pemerintahan merupakan momentum penting sebagai tonggak dimulainya penyelenggaraan pemerintahan yang baik guna mengaktualisasikan secara khusus norma konstitusi yang mengatur hubungan antara negara dan warga masyarakat, setiap Keputusan dan/atau tindakan pemerintahan harus didasarkan ketentuan peraturan perundang - undangan yang berlaku dan Asas-Asas Umum Pemerintahan Yang Baik.

2. Peraturan Mahkamah Agung Republik Indonesia Nomor 5 tahun 2015 tentang Pedoman Beracara untuk memperoleh putusan atas penerimaan permohonan guna mendapatkan keputusan dan/atau tindakan Badan atau Pejabat Pemerintahan, yang kemudian disempurnakan dengan Peraturan Mahkamah Agung Republik Indonesia Nomor 8 tahun 2017, mengatur prosedur dan mekanisme beracara dalam mengajukan permohonan di PTUN untuk memperoleh putusan atas penerimaan permohonan guna mendapatkan keputusan dan/atau tindakan Badan atau Pejabat Pemerintahan.

Kedudukan Peraturan Mahkamah Agung meskipun tidak tercantum secara eksplisit dalam hierarkhis peraturan perundangundangan sebagaimana diatur dalam Pasal
7 ayat (1) Undang-Undang Nomor 12 Tahun 2011 tentang Pembentukan Peraturan perundang undangan, namun berdasarkan ketentuan Pasal 8 ayat (2) memiliki kekuatan mengikat sebagaimana peraturan perundang - undangan yang lain.

\section{DAFTAR PUSTAKA}

Undang Undang Dasar Republik Indonesia 1945 dan Perubahannya,Penabur Ilmu, Jakarta;

Abdullah Rozali, 2005, Hukum Acara Peradilan Tata Usaba Negara,cet.II. PT.Raja Grafindo Persada, Jakarta;

Undang Undang Nomor 5 Tahun 1986 Tentang Peradilan Tata Usaha Negara, 1990, Pustaka Tinta Mas, Cet IV.Surabaya;

Undang Undang Nomr 12 Tahun 2011 Tentang Pembentukan Peraturan Perundang Undangan, 2011.cet I. Ditjen Perundang Undangan Kementerian Hukum dan HAM RI, Jakarta;

Putriyanti Ayu, Kartika, 2015 , Kajian Undang Undang Administrasi Pemerintahan Dalam Kaitan dengan Peradilan Tata Usaba Negara, Tesis , Fakultas Hukum Universitas Diponegoro

Setyabudhi,Donni 2014. Keputusan Fiktif Negatif Sebagai Dasar Pengajuan Gugatan Dalam Sengekata Tata Usaha Negara Yang Berkaitan Dengan Pelayanan di Bidang Pertanahan, Makalah.

Hamzah M.Guntur, 2015, Paradigma Baru Penyelenggaraan Pemerintahan Berdasarkan Undang Undang Administrasi Pemerintahan, Makalah.

Putusan Pengadilan Tata Usaha Negara Surabaya Nomor: 45/G/2014/P.TUN.SBY tanggal 17 Juli 2014; 